\title{
L'espace collectif et les conflits chez les Aï Bou Guemez du Haut-Atlas central (Maroc)
}

Béatrice Lecestre-Rollier

\section{(2) OpenEdition \\ Journals}

Édition électronique

URL : https://journals.openedition.org/tc/906

DOI : $10.4000 /$ tc.906

ISSN : 1952-420X

Éditeur

Éditions de l'EHESS

Édition imprimée

Date de publication : 1 septembre 1986

ISSN : 0248-6016

\section{Référence électronique}

Béatrice Lecestre-Rollier, «L'espace collectif et les conflits chez les Aït Bou Guemez du Haut-Atlas central (Maroc) », Techniques \& Culture [En ligne], 7| 1986, mis en ligne le 23 janvier 2006, consulté le 29 septembre 2022. URL : http://journals.openedition.org/tc/906 ; DOI : https://doi.org/10.4000/tc. 906

Ce document a été généré automatiquement le 29 septembre 2022.

Tous droits réservés 
L'espace collectif et les conflits chez les Aït Bou Guemez du Haut-Atlas central (Maroc)

Béatrice Lecestre-Rollier 